\title{
PEREMPUAN-PEREMPUAN YANG PENUH KARUNIA : URAIAN SINGKAT TENTANG KISAH PEREMPUAN MANDUL DAN PERAWAN DALAM INJIL LUKAS 1
}

\author{
Muryati Setianto $^{1}$, Christian Reynaldi ${ }^{2}$ \\ ${ }^{1}$ Sekolah Tinggi Teologi Bethel Indonesia, muryati@sttbi.ac.id \\ ${ }^{2}$ Seminari Alkitab Asia Tenggara Malang, christian_reynaldi_widodo@hotmail.com
}

\begin{abstract}
How does the New Testament view role of women in Christian community? The answers to that questions can be found in a number of books in the New Testament. Of these, one that stands out is the Gospel of Luke. In this article we argues that Luke presents the story of the gospel by highlighting minorities, especially women. This is proven from many sections in the Gospel of Luke, for example: Luke 1. We explore three stories in Luke 1 namely: the birth of John the Baptist foretold (vv. 5-25), the birth of Jesus foretold (vv. 26-38), and Mary visits Elizabeth (vv. 39-45). All three stories show the significance of Mary and Elizabeth's role as women who receive gifts from God. To this gift they show an appropriate faith response. Mary is told as a woman who is obedient and ready to carry out God's message through the angel Gabriel. Elizabeth is told as a woman who is barren but has integrity, and shows faith in the movement of the Holy Spirit within her. Both have an important role in the birth of Jesus Christ, the Messiah and the Savior. Both figures show that women can be used by the Holy Spirit. Through empowerment by the Holy Spirit women have gifts that can be used for the common good in the Christian community. The New Testament never ruled out the role of women in the Christian community.
\end{abstract}

Keywords: : women; gospel; gift; luke

\begin{abstract}
Abstrak
Bagaimana Perjanjian Baru memandang peran perempuan dalam komunitas Kristen? Jawaban dari pertanyaan tersebut dapat ditemukan dalam sejumlah kitab di Perjanjian Baru. Dari sekian kitab tersebut, salah satu yang menonjol adalah Injil Lukas. Dalam artikel ini peneliti berargumentasi bahwa Lukas mempresentasikian kisah Injil dengan menonjolkan kaum minoritas, khususnya kaum perempuan. Hal ini nampak dari banyak bagian di dalam Injil Lukas, salah satunya adalah Lukas 1 . Peneliti mengeksplorasi tiga kisah dalam Lukas 1 yaitu: pemberitahuan tentang kelahiran Yohanes Pembaptis (ay. 5-25), pemberitahuan tentang kelahiran Yesus (ay. 26-38), dan perjumpaan Maria dengan Elisabet (ay. 39-45). Ketiga kisah tersebut memperlihatkan signifikansi peran Maria dan Elisabet sebagai perempuan yang mendapatkan karunia dari Tuhan Allah. Terhadap karunia tersebut mereka menunjukkan respon iman yang tepat. Maria dikisahkan sebagai perempuan yang taat dan siap melaksanakan pesan Tuhan melalui malaikat Gabriel. Elisabet dikisahkan sebagai perempuan yang mandul tetapi berintegritas, dan menunjukkan iman kepada gerakan Roh Kudus di dalam dirinya. Keduanya mempunyai peran penting di dalam kelahiran Yesus Kristus, Sang Mesias dan Juruselamat. Kedua tokoh tersebut memperlihatkan bahwa perempuan dapat dipakai oleh Roh Kudus. Melalui pemberdayaan oleh Roh Kudus perempuan mempunyai karunia yang dapat dipakai demi kepentingan bersama dalam komunitas Kristen. Perjanjian Baru tidak pernah mengesampingkan peran perempuan dalam komunitas Kristen.
\end{abstract}

Kata Kunci: perempuan; injil; karunia; lukas 


\section{PENDAHULUAN}

Harus diakui bahwa peneliti Injil Lukas kerap kali menyebutkan perempuan ${ }^{1}$ dibandingkan dengan Injil lainnya, ${ }^{2}$ dan terlebih penting mereka memainkan peran yang signifikan. Lukas memberikan tempat yang sangat khusus untuk perempuan, sehingga tidak heran William Barclay menyebutnya "the Gospel of women." Peneliti Injil Lukas mengedepankan perempuan Yahudi yang terpinggirkan dalam budayanya. Dalam budaya Yahudi perempuan tidak dihargai dan dianggap sebagai kaum yang rendah martabatnya. Perempuan juga dipandang tak ada bedanya dengan barang yang dapat dimiliki atau dibuang. Kedudukan perempuan yang rendah ini juga bisa dilihat ketika seorang laki-laki Yahudi berdoa "terpujilah Tuhan yang tidak menciptakanku sebagai seorang perempuan."3 Hal ini telah berkembang hampir di semua lapisan masyarakat Yahudi. Sama halnya di abad pertama periode Yunani-Romawi, perempuan dianggap bagian yang terpinggirkan. Dowling mengutip pendapat Aristoteles yang menggambarkan perempuan sebagai kaum inferior, "The male is by nature superior and the female inferior, the male ruler and the female subject." 4

Potret perempuan yang sangat menonjol dalam Injil Lukas sudah terlihat sejak awal Injil ini ditulis. Elisabet dan
Maria dikisahkan sebagai dua perempuan yang dipakai Tuhan terkait rencana keselamatanNya. Keduanya berperan dalam kisah 2 kelahiran ajaib. Kisah pemberitahuan kelahiran Yohanes (Luk 1:5-25) disejajarkan dengan kisah pemberitahuan kelahiran Yesus (1:26-38). Melalui kesejajaran ini Lukas menekankan tugas mereka, serta perbedaan antara Yohanes sebagai pendahulu (forerunner) dan Yesus sebagai Mesias. Dalam kesejajaran ini juga tercermin unsur-unsur yang terkait diantaranya: malaikat yang sama, Gabriel menampakkan diri kepada Zakharia dan Maria; ditampilkan sosok Elisabet yang mandul dan Maria seorang perawan yang bertunangan dengan Yusuf dari garis keturunan Daud; keduanya akan melahirkan seorang anak laki-laki; kedua kelahiran tersebut dikaitkan dengan pekerjaan Roh Kudus; baik Elisabet maupun Maria dipenuhi oleh Roh Kudus, dan masing-masing sedang mengandung bayi yang memiliki peran yang berpusat pada rencana kekal Tuhan bagi umatNya.

Lukas menempatkan kisah kelahiranYohanes Pembaptis dan Yesus dalam dunia Yudaisme dan konteks historis dan geografis dunia Mediterania di abad pertama. Kisah kelahiranYohanes dan Yesus melanjutkan kisah yang sedang berlangsung tentang inisiatif keselamatan Allah sebagaimana diceritakan melalui 
Perjanjian Lama. Lukas

"menenggelamkan" pembacanya ke dalam dunia Yudaisme melalui kisah kelahiran Yesus beranjak dari masa kini ke masa lampau, janji keselamatan dari Allah sebagaimana nampak dari kitab-kitab PL, dibawa ke masa kini melalui kisah tentang pemberitahuan serta kelahiran Yohanes Pembaptis dan Yesus. ${ }^{5}$

\section{PEMBAHASAN}

Elisabet, perempuan mandul (Luk. 1:525)

Kisah pemberitahuan kelahiran Yohanes (Luk. 1: 5-23), dibuka dengan menampilkan orang tua Yohanes, yaitu: Zakharia dan Elizabeth. Pengantar ini menempatkan cerita dalam kerangka Yudaisme Perjanjian Lama. Zakharia adalah seorang imam, dari rombongan Abia (ayat 5). Elizabeth, istrinya berasal dari keluarga imam Harun. Lukas memperkenalkan baik Elizabeth maupun Zakharia sebagai karakter yang sama pentingnya. Mereka sebagai orang benar ${ }^{6}$ dan tidak bercela. ${ }^{7}$ Karakter tersebut epenuhnya sesuai dengan kehendak Allah namun Elisabet mandul dan sudah melewati usia subur. Deskripsi ini menjadi penting untuk memastikan bahwa pasangan yang tidak memiliki anak ini (mandul) tidak dipahami oleh pembaca sebagai akibat dari kejahatan atau tidak layak dimata Tuhan.

Kisah mereka ditempatkan dalam tradisi Abram dan Sarai (Kej. 11:30; 16:1);
Ishak dan Ribka (Kej. 25:21); serta Yakub dan Rahel (30:1). ${ }^{8}$ Pada masa itu bila seorang perempuan yang bersuami tidak memiliki anak maka ia dianggap tidak beruntung. Kemandulan dianggap kegagalan seorang perempuan, penghukuman dosa (Im. 20: 20-21 bnd. 2 Samuel 6:23), hal yang memalukan, mencemarkan atau aib (perhatikan ayat 25 hal itu disebut sebagai 'aib' [NIV / NASB: disgrace $(=\quad$ sesuatu yang memalukan, mencemarkan)]. Anggapan tersebut didukung oleh penafsiran dari William Barclay, "Jewish Rabbis said that 7 people were excommunicated from God and the list began, 'A Jew who has no wife, or a Jew who has a wife and who has no child." " Namun di sisi lain Allah diangkap sebagai Pribadi yang menyebabkan kondisi tersebut (lihat kasus pararel dengan Rahel di Kej. 30:1-24; Hana di 1Sam. 1:6; anak sebagai pemberian Allah di Kej. 33:5; Mzm. 127:3).

Lebih lanjut Lukas memperkenalkan malaikat Tuhan, ${ }^{10}$ Gabriel $^{11}$ untuk menguatkan gagasan kehadiran Allah di Bait Suci, tempat dimana Zakharia melayani sebagai imam. Sementara Zakharia sedang melakukan tugas keimamannya (membakar ukupan, ayat 8-9), malaikat Tuhan datang membawa pemberitahuan mengenai kelahiran Yohanes (ayat 13). Anak itu akan dinamai Yohanes (ayat 13) yang diartikan "Yahweh has shown favor," yang kemudian dikenal 
dengan sebutan Yohanes Pembaptis. Ketika Tuhan menamai seorang anak, anak itu secara khusus sangat penting dalam rencana Tuhan (Kej. 16:8, 11; 17:19; 1Raj. 13:2;Yes. 7:14; 49:1; Mat. 1:21; Luk. 1:31). Yohanes akan menjadi besar di hadapan Tuhan (ayat 15), bahkan Yesus berkata, “...yang dilahirkan oleh perempuan tidak ada seorangpun yang lebih besar dari pada Yohanes" (7:28). Yang lebih penting lagi ia akan dipenuhi oleh Roh Kudus ${ }^{12}$ (bnd.. $1: 41,67)$ mulai dari rahim ibunya ("even from his birth, lit still from the womb of his mother"). Janji ini mulai digenapi pada peristiwa-peristiwa yang tercatat dalam Lukas 1:39-45, khususnya ayat 44. Tetapi Roh Kudus yang berdiam dengan Yohanes adalah intensifikasi kehadiran Roh Allah di antara nabi Perjanjian Lama (1Sam. 10:10; 2Raj. 2:9-16, lihat Yes. 61:1; Yeh. 11:5; Y1. 2:28). Segala sesuatu tentang peristiwaperistiwa ini dimulai pada jaman PL, tetapi sekaligus menunjukkan peningkatan dari aktivitas ilahi serta datangnya suatu jaman yang baru.

Yohanes akan menjadi seorang nabi yang "membuat orang Israel berbalik kepada Tuhan dan hati bapa kepada anakanaknya" (Luk. 1:16-17). Ungkapan berbalik berakar dari Perjanjian Lama (U1 30:2; Hos. 3:5; 7:10). Berbicara tentang hal ini Lukas menunjukkan bahwa Yohanes akan mengalihkan mereka yang merespon terhadap pesannya ke arah jalan Tuhan dan pemulihan dengan Tuhan akan membuahkan pemulihan dengan yang lain. Dengan demikian Yohanes akan "menyiapkan bagi Tuhan suatu umat yang layak bagi-Nya" (bnd. Yes. 43:7; 2Sam. 7:24). Mereka akan menjadi umat Allah yang dipanggil kepadaNya, sisa umat yang setia yang menikmati penggenapan janji Allah karena mereka berbalik kepada Allah. Yohanes menjadi seperti Elia dalam pelayanannya sebagai "perintis jalan"13 (1Raj. 17-18; Mal. 4:5; Mat. 11:7-15; 27:47; Yoh. 1:21 bnd. Sir. 48:10). Lukas mendeskripsikan diri Yohanes untuk menunjukkan peranannya dalam sejarah keselamatan yang ditandai dengan kelahirannya yang ajaib serta panggilan ilahi untuk mempersiapkan kedatangan Mesias.

Di bagian lain Lukas juga menginformasikan bahwa kunjugan malaikat Tuhan mengenai pemberitahuan kelahiran merupakan hal yang umum di Perjanjian Lama (lihat Kej. 16:10-11; 17:15-19; 18:10-15; 25:23; Hak. 13:3-21). Namun ada hal yang tidak biasa, dimana seorang pria yang menerima pesan dan bukan perempuan. Informasi ini menjadi penting untuk mengkontraskan tanggapan Zakharia dan Elisabet terhadap pesan yang disampaikan malaikat Tuhan. Meskipun Elizabet tidak mengalami secara langsung penampakan malaikat Tuhan, penafsirannya terhadap tanda kehadiran Tuhan bertentangan dengan tanggapan ketidak percayaan ${ }^{14}$ Zakharia (Luk. 1:18-20 
bnd. ayat 24-25). Elizabet, berbeda dengan Zakharia, mengakui anugerah Tuhan. Ia yang mengumumkan kehamilannya sebagai karunia Tuhan, "Inilah suatu perbuatan Tuhan bagiku, dan sekarang Ia berkenan menghapuskan aibku di depan orang." (ayat 25). Mengandungnya Elisabet menjadi peristiwa mukjizat yang besar karena seorang perempuan yang sudah tua dan mandul pun ternyata bisa mengandung seorang anak. Tanggapan iman Elisabet sangat tajam, berbeda dengan Zakharia. Ia memahami bahwa ini merupakan ekspresi belas kasihan Allah dan memahami kehamilannya dalam terang nubuat PL. ${ }^{15}$

Maria, perawan dari Nazaret (Lukas 1:26-38)

Lukas memberikan informasi penting terkait dengan pemberitahuan kelahiran Yesus kepada Maria. Keterangan waktu dalam bulan yang keenam Elisabet mengandung Yohanes, Allah mengutus malaikat Gabriel (Luk. 1:25, 26, 36). Keterangan waktu ini hendak menjelaskan bahwa kisah tentang kunjungan malaikat kepada Maria merupakan lanjutan dari penampakannya kepada Zakharia (1:5-25). Allah mengutus malaikat Gabriel ${ }^{16}$ untuk menyampaikan rencana Allah itu berlangsung secara berkelanjutan dengan tujuan pada keselamatan.

Selain keterangan waktu, ditunjukkan juga keterangan tempat yaitu kota Nazaret di Galilea. Nazaret merupakan kota yang terletak cukup dekat dengan beberapa jalur perdagangan terpenting untuk hubungan dengan dunia luar. Akan tetapi, letaknya sebagai kota terdepan di perbatasan selatan Zebulon yang mengawasi dataran Esdraelon, mengakibatkan kedudukannya agak terpencil. Oleh sebab itu, penduduknya pun memperlihatkan sifat tertentu sebagai orang Yahudi yang udik dan totok sehingga orang Nazaret dipandang rendah. Tempat tinggal kediaman penduduk di kota tersebut hanya berupa gua-gua di lereng bukit dengan pintu masuk terbuat dari papan. Lukas ingin memberi perhatian terhadap tempat-tempat yang kecil, miskin, tidak diperhatikan. Charles berkomentar, "Luke contrasts the greatness of the setting of the announcement about John with the simplicity of the announcement about Jesus. The tone of the setting of Jesus's birth matches the tone of his ministry.The great God of heaven sends the gift of salvation to humans in a serene unadorned package of simplicity." 17

Penampakan malaikat Tuhan di Nazaret menunjukkan bahwa Maria berasal dari kalangan sederhana (ayat 27). Lukas memperkenalkan sosok Maria sebagai seorang perawan. ${ }^{18} \quad$ Kondisinya terkonfirmasi di ayat 34, "where she confesses her lack of sexual experiences." Jelas bahwa hal ini mengkaitkan asal mula Yesus dengan Roh Kudus ( ayat 34-35). Matius setuju dengan hal ini (lihat Matius 1:23). Kelahiran dari seorang perawan 
merupakan salah satu tanda superioritas Yesus yang melebihi Yohanes Pembaptis. Ini menjadikan Yesus sangat unik.

Maria adalah seorang perawan yang bertunangan $^{19}$ dengan Yusuf dari keturunan Daud. Keturunan Daud ini penting yang menghubungkan kepada Yusuf dan kepada Yesus melalui dia. Yusuf dibutuhkan sebagai bapak biologis dengan tujuan untuk meneruskan silsilah itu kepada Yesus. Menarik di dalam cerita ini, Lukas lebih menonjolkan pribadi Maria sekalipun, ia adalah perempuan, daripada dengan pribadi Yusuf (bnd.. Mat. 1:18-25). Padahal tradisi Yahudi merupakan tradisi patriarkal yang lebih mengutamakan laki-laki. Pandangan ini semakin mempertegas fokus ajaran Lukas yang menekankan perhatian kepada sosok perempuan, yang juga tergolong dalam kaum miskin.

Kemudian malaikat Gabriel menyampaikan salam. Salam ini menjadikan Maria yang dahulunya tidak dikenal pada akhirnya dikenal sebagai "Yang Dikaruniai" atau "Yang Terberkati" (ayat 28 bnd.. 30 "Jangan takut, hai Maria, sebab engkau beroleh kasih karunia di hadapan Allah"). ${ }^{20}$ Frasa "beroleh kasih karunia" dalam bahasa Yunani menggunakan kata kekharitômenè ${ }^{21}$ yang menegaskan anugerah. Istilah kekharitômenè ini mengandung unsur kegembiraan/kegirangan, keagungan, dan mengandung rahmat. ${ }^{22}$ Dalam konteks ini Maria memperoleh anugerah Tuhan. Maria dihargai oleh Tuhan bukan disebabkan kebaikan atau apa yang telah dikerjakannya, namun dipilih sebagai sarana Tuhan untuk mendemonstrasikan anugerah Tuhan. Tidak hanya salam, malaikat pun memberikan penegasan, "Tuhan menyertai engkau" Keterbukaan yang ditunjukkan Maria bagi anugerah Allah membuat kasih-Nya dapat dicurahkan sepenuhnya ke dalam hidup seseorang tanpa mendapat hambatan. Karena Maria telah dipilih oleh Allah, ia pun mendapatkan rahmat dari Allah sendiri. ${ }^{23}$

Di sini Lukas tidak bermaksud mengarahkan perhatian kita pada penampakan malaikat, melainkan pada pesan yang disampaikan kepada Maria. Salam awal malaikat Gabriel kepada Maria mengandung misi tersembunyi: membawa kabar yang menggembirakan bahwa Maria akan mengandung dan melahirkan seorang anak laki-laki (ayat 30). Malaikat memberitahukan kepada Maria bahwa ia akan menjadi ibu penyelamat, seperti terungkap dalam arti nama "Yesus". ${ }^{24}$ Memang sebenarnya nama "Yesus" berarti “penyelamat." Pesan Gabriel menekankan 3 hal mengenai Yesus : posisi-Nya (ayat 32, "Anak Allah yang maha tinggi”); otoritasNya (ayat 33 bnd. , "raja atas Isarel selamanya, kerajaan-Nya tidak akan berkesudahan"); dan ikatan ilahi-Nya (ayat 35, "Roh Kudus akan turun atasmu dan kuasa Allah Yang Mahatinggi akan menaungi engkau...”). 
Singkatnya, Yesus adalah raja yang dijanjikan dari garis keturunan Daud. Konsep raja keturunan Daud bermula dalam Perjanjian Lama (2Sam. 7:8-17; Mzm. 89; 132; Yes. 9:5-6; 11:1-5,10; Yer. 23:5-6). ${ }^{25}$ Perspektif kerajaan disini adalah kerajaan Mesianis yang dijanjikan. Lukas mengembangkan dan memperluas pemahaman PL mengenai kerajaan itu melalui pengajaran Yesus, pelayanan Yohanes Pembaptis dan mujizat-mujizatNya. Perluasan tersebut tidak membatalkan yang telah dijanjikan dalam PL tetapi melengkapinya. Tuhan akan menyempurnakan janji-janji yang dibuat untuk Israel sebagai penerima mula-mula dari janjiNya, bahkan saat Ia memperluas janji itu di masa Perjanjian Baru sampai melibatkan bangsa-bangsa bukan Yahudi (Gentile).

Salam itu menjadi introduksi apik dan menarik yang digunakan oleh Lukas dalam mengantarkan pembaca dan pendengarnya untuk mengenal sosok Maria. Pada akhirnya dari hanya sebatas salam, sapaan itu menjadi predikat kuat yang melekat pada figur Maria, "Perempuan Yang Dikaruniai dan Terberkati dari Nazaret."26 Potret Maria yang dilukiskan Lukas adalah signifikan: model orang percaya yang menerima pesan Tuhan berbeda dengan Zakharia (ayat 37-38); mendapat karunia dari Tuhan (ayat 30); bijaksana (ayat 29 bnd. 2:9,51); taat (ayat 38 ); percaya (ayat 45); penyembah (ayat
46); sebagai hamba Tuhan (ayat 38 bnd. 48), pengakuan ini sebagai bentuk penyerahan kepada tujuan Allah dan perannya dalam membantu tujuan itu. Selanjutnya dalam menggambarkan dirinya sebagai hamba Tuhan, ia menglaim tempat dalam keluarga Tuhan. Hal tersebut disampaikan oleh Green dengan tepat,

She who has been given no family heritage by the narrator now affirms her place in God's family. God's favour and election are the only indicators of status that have been given to Mary.' ... 'When Mary asserts her position as the servant of the Lord, we recognise that she derives her status from God, and so Luke is now initiating his representation of a community of God's people whose fundamental social experience is grounded in their relationship to God. ${ }^{27}$

\section{Maria mengunjungi Elisabet (Lukas 1:39-56)}

Lukas mencatat perjumpaan dua perempuan yang penuh karunia, Maria dengan Elisabet yang tengah mengandung 6 bulan. Perjumpaan ini berfungsi sebagai poros penting dalam "infancy narrative" (narasi kelahiran). Perjumpaan tersebut mengingatkan perkataan malaikat Tuhan kepada Maria, "Dan sesungguhnya, Elisabet, sanakmu itu, ia pun sedang mengandung seorang anak laki-laki pada 
hari tuanya dan inilah bulan yang keenam bagi dia, yang disebut mandul itu."(ayat 36). Kata-kata ini juga secara tidak langsung membawa Maria untuk mengunjungi Elisabet, saudaranya. Melalui pertemuan langsung tersebut Maria menerima anugerah terindah melalui pemberitaan ini. Meskipun yang bertemu adalah ibu dari Yesus dan Yohanes bertemu, kisah ini digambarkan sebagai pertemuan kedua anak, karena Yohanes bereaksi terhadap pertemuan itu.

Pertemuan dua perempuan ini diawali oleh salam Maria kepada Elisabet di rumah Zakharia sekali pun tidak dijelaskan isi salam tersebut (hanya disebutkan 3 kali ayat $40,41,44)$. Hal yang menarik salam Maria itu membangkitkan tanggapan Elisabet: "melonjaklah anak yang dalam rahimnya." ${ }^{28}$ Elisabet dipenuhi Roh Kudus (ayat 41 bnd. ayat 15). Reaksi bayi Yohanes dimaksudkan untuk membuktikan kebenaran dan penggenapan dari nubuat malaikat Gabriel dalam Lukas 1:31-33,35, sekaligus mencerminkan peran pendahulu sebagai pembuka jalan bagi Mesias (1:17,76 bnd. pasal 3).

Frasa "Elizabet yang dipenuhi Roh Kudus", menawarkan dua berkat kepada Maria. Dalam berkat pertamanya, Elizabet menegaskan berkat Allah bagi Maria, "Diberkatilah engkau di antara semua perempuan dan diberkatilah buah rahimmu" (ayat 42). Ungkapan "Diberkatilah engkau di antara semua perempuan" ("Blessed are you among women" bnd. Hak. 5:24; Yudit 13:18), ini merupakan kebiasaan Semitik untuk mengatakan "paling diberkati". Menurut pemahaman Yahudi kontemporer gagasan mengenai keagungan perempuan diukur oleh anak-anak yang dia lahirkan. ${ }^{29}$ Dalam konteks ini Maria diberkati bukan semata-mata karena imannya, melainkan pada anaknya dan keagungan-Nya. Bayi yang ada dalam kandungan Maria inilah yang membuat Maria disebut berbahagia/diberkati. Bahkan Elisabet menyebut Maria sebagai ibu Tuhanku (ayat 43).

Dalam berkat keduanya, Maria diakui sebagai pribadi yang beriman dan sebagai penerima keberuntungan ilahi karena imannya (ayat 45). Iman Maria dikontraskan dengan ketidak percayaan atau kurangnya iman Zakharia (ayat 20). Sesungguhnya Lukas berusaha untuk memaksimalkan peran Maria sebagai contoh orang percaya. Pada bagian ini Maria disebut berbahagia sebab imannya tetapi disebut yang paling berbahagia di ayat 42 sebab hak istimewa menjadi ibu dari anak Allah. Elizabet menegaskan bahwa apa yang sedang terjadi adalah penggenapan dari apa yang diucapkan kepadanya dari Tuhan (ayat 45).

Pertemuan Maria dengan Elisabet diakhiri dengan nyanyian pujian Maria yang dikenal dengan Magnificat Maria (ayat 4655). Pujiannya adalah bersifat pribadi, di mana jiwa dan rohnya menaikkan pujian. 
Dalam Magnificat, Maria menaikkan nyanyian pujian atas kebaikan dan kesetiaan Tuhan dalam rencana keselamatanNya bagi umat manusia, khususnya bagi umat Allah, Israel. Maria menyadari bahwa kelahiran anaknya adalah penggenapan janji-janji perjanjian kepada Abraham dan umatNya. Maria mendeskripsikan karya Tuhan yang Maha Kuasa dan anugerah/rahmat yang Ia nyatakan kepada bangsa Israel, serta penggenapan janji Allah kepada Abraham. Selain itu Magnificat juga menunjukkan bagaimana respon Maria terhadap kehendak Tuhan yang dinyatakan melalui dirinya. Dengan sukacita ia taat menjalani kehendak Tuhan yang hendak memakai rahimnya. Magnificat ini diakhiri dengan suatu jaminan bahwa Tuhan selalu setia kepada perjanjian dengan umat-Nya.

\section{KESIMPULAN}

Lukas seorang narator ulung yang mengemas cerita dengan apik dan menarik. Menampilkan dua perempuan yang berperan penting dan signifikan dalam pembukaan Lukas 1. Dengan menampilkan dua potret perempuan yang berbeda kondisi, mandul dan perawan masuk dalam rancangan keselamatan Tuhan. Lukas menepis belenggu budaya yang merengut kebebasan kaum perempuan. Rancangan keselamatan Tuhan melampaui budaya manusia. Tuhan bebas memilih siapa pun yang berhak untuk memperoleh karuaniaNya. Maria dan Elizabet menunjukkan sifat kolaborasi manusia dalam menanggapi karunia Tuhan.

\section{DAFTAR PUSTAKA}

Barclay, William. The New Daily Study Bible, The Gospel of Luke. Wesminster John Knox Press, 2001. Bauckham, R.J. "Gabriel." Dalam Enslikopedi Alkitab Masa Kini, Jilid I $(A-L)$. Diedit oleh J.D. Douglas. Diterjemahkan oleh J.M. Pattiasina, Jakarta: Yayasan Komunikasi Bina Kasih, 2011.

Bock, Darrell L. Luke. The IVP New Testament Commentary. Downers Grove: InterVersity, 1994.

Charley, J.W. "Nazaret." Dalam Enslikopedi Alkitab Masa Kini, Jilid $2(M-Z)$. Diedit oleh J.D. Douglas. Diterjemahkan oleh Andar Lumantobing. Disunting oleh H.A. Omposunggu. Jakarta: Yayasan Komunikasi Bina Kasih, 2011.

Coleridge, Mark. The Birth of the Lukan Narrative: Narrative as Christology in Luke 1-2. Sheffield: Sheffield Academic Press, 1993.

Dowling, Elisabeth V. Taking Away the Pound : Women, Theology and The Parable of the Pounds in the Gospel of Luke. Library Of New Testament Studies. London :T\&T Clark, 2007. 
Galot, Jean Galot. Mary In The Gospel.

Westminster: The Newman Press, 1965.

Green, Joel. The Gospel of Luke. The New

International Commentary on the

New Testament. Grand Rapids:

Eerdmans, 1997.

Reid, Barbara E. Choosing The Better

Part?: Women in The Gospel of
Luke. Message of the Fathers of the

Church. Collegeville: Michael

Glazier Books, 1996.

Stein, Robert H. Luke. The New American

Commentary of Luke. Vol. 24.

Nashville: Braodman \& Holman,

1992.

${ }^{1}$ Maria, ibu Yesus (Luk. 1:26-38, 46-55); Elisabet, ibu Yohanes (1:39-45,57-60); Hana, seorang nabi perempuan (2:36-38); seorang janda dari Nain (7:11-15); seorang perempuan yang berdosa di rumah Simon (7:3650); Maria yang disebut Magdalena yang telah dibebaskan dari tujuh roh jahat (Lukas 8:2-3); anak Yairus dan perempuan yang mengalami pendarahan 12 tahun (Lukas 8:40-56); Maria dan Marta di Betani (10:38-42).

${ }^{2}$ Barbara E. Reid, Choosing The Better Part?: Women in The Gospel of Luke, Message of the Fathers of the Church (Collegeville: Michael Glazier Books, 1996), 2.

${ }^{3}$ Bandingkan dengan pandangan Bapa Gereja megenai kedudukan kaum perempuan, diantaranya: Clement of Alexandria, "Every woman should be filled with the shame by thought that is a woman"; Agustinus mempersalahkan perempuan dalam kejatuhan manusia dalam dosa. Ia berpendapat bahwa setan terlebih dahulu menggoda manusia yang lebih inferior dan lebih mudah berdoasa yaitu perempuan; selanjutnya Thomas Aquinas pun melihat perempuan lebih inferioir dari pada pria, perempuan hanya diciptakan untuk fungsi prokreasi (menghasilkan keturunan); sama halnya dengan apa yang diyakini oleh Pope Gregory I yang berpendapat bahwa perempuan itu lebih lemah, lamban dalam memahami, serta memiliki pikiran yang tidak stabil dan naif. Baginya, "kegunaan seorang perempuan hanyalah sebatas fungsi reproduksi dan fungsi seorang ibu."

${ }^{4}$ Elisabeth V. Dowling, Taking Away the Pound: Women, Theology and The Parable of the Pounds in the Gospel of Luke, Library Of New Testament Studies (London :T\&T Clark, 2007), 12-13.

${ }^{5}$ Mark Coleridge The Birth of the Lukan Narrative: Narrative as Christology in Luke 1-2 (Sheffield: Sheffield Academic Press, 1993), 30-35.

${ }^{6}$ Elizabeth dikatakan benar (dikaios). Dalam Alkitab kata sifat ini jarang digunakan untuk menggambarkan seorang perempuan. Dalam terjemahan Akkitab Ibrani terjemahan Yunani, kata dikaios sering digunakan untuk menggambarkan Tuhan (Yes. 45:21; Yer. 12:1; Dan. 9:14; 2Taw. 12:6) dan dikenakan untuk individu seperti Nuh (Kej. 6:9); Ayub (Ayb. 1:1); Isyboset anak Saul (2 Sam. 4:11); hamba Allah (Yes. 53:11) dan Tamar merupakan perempuan satu-satunya yang disebutkan benar (Kej. 38:26); Dalam Perjanjian Baru dikenakan untuk Tuhan (Rm. 3:26; 2Tim. 4:8; 1Yoh. 1:9); Yusuf (Mat. 1:19); Yohanes Pembaptis (Mrk. 6:20); Simeon (Luk. 2:25); Yusuf dari Arimatea (23:50); Kornelius (Kis. 10:22); Habel (Ibr. 11:4; 1 Yoh. 3:12) dan Lot (2Ptr. 2:7).

${ }^{7}$ Dalam Yunaninya poreusthai, diterjemahkan "lived blamelessly" (har., "walking blamelessly"). Lukas menggunakan kata ini dalam arti etika perilaku.

${ }^{8}$ Dalam narasi tentang para perempuan mandul yang disebutkan dalam Perjanjian Lama seperti Sara, Ribka, Rahel, dan Hana, pada akhirnya mempunyai seorang anak, anak lai-laki. Sara yang mandul (Kej 16: 1) akhirnya melahirkan seorang anak laki-laki yang diberi nama Ishak (Kej 21:2). Ribka yang mandul akhirnya melahirkan anak kembar, Esau dan Yakub (Kej 25:21). Rahel yang mandul (Kej 29:31) akhirnya melahirkan anak laki-laki yang dinamai Yusuf (Kej 30: 22-24) bahkan beberapa waktu kemudian Rahel melahirkan anak kedua yakni Benyamin (Kej 35: 16-17). Dalam konteks PL, yakni adat istiadat Yahudi, memang sangat penting adanya anak dalam keluarga, sebagaimana dituliskan Sakenfeld : Having children, especially sons, was of central importance in Israel's culture, as it was in other surrounding cultures and still is in most cultures today. (Sons have the privilege abd responsibility of carrying on the family name and inheriting the family property).

13.

${ }^{9}$ William Barclay, The New Daily Study Bible, The Gospel Of Luke, (Wesminster John Knox Press, 2001),

${ }^{10}$ Malaikat bisa disamakan dengan Allah (bnd. Kej. 16:7; 21:17; 22:11;13:13; Kel. 3:2; Hak. 6:11).

${ }^{11}$ Gabriel dalam bahasa Ibrani, Gavri’èl, artinya "utusan Allah" atau "kekuatan Allah." R.J. Bauckham, “Gabriel,” dalam Enslikopedi Alkitab Masa Kini, Jilid I (A - L), terj. J.M. Pattiasina, ed. J.D. Douglas (Jakarta: 
Yayasan Komunikasi Bina Kasih, 2011), 318. Di Perjanjian Lama hanya muncul di kitab Daniel, lihat Daniel $8: 17 ; 9: 20-21 ; 10: 7$.

${ }^{12}$ Pekerjaan Roh Kudus adalah penekanan yang disukai oleh Lukas dalam tulisannya.

${ }^{13}$ Gereja mula-mula juga menerima nubuatan Maleakhi mengenai sang "perintis" telah digenapi sepenuhnya dalam Yohanes yang memberitakan permulaan kerajaan Mesias yang diwujudkan oleh kedatangan Yesus sebagai Kristus (Markus 1:2-8). their time",

${ }^{14}$ Tanggapan Zakharia didasari kondisinya dan Elisabet yang sudah tua, mandul, sudah melewati "past

${ }^{15}$ Bnd.. tokoh Sarah (Kej. 21:1) dan Rahel (30:23).

${ }^{16}$ Gabriel dalam bahasa Ibrani, Gavri'èl, artinya utusan Allah atau kekuatan Allah. Lihat Bauckham, “Gabriel”, 318. Di Perjanjian Lama hanya muncul di kitab Daniel, lihat Daniel 8:17; 9:20-21; 10:7.

${ }^{17}$ J.W. Charles, "Nazaret," dalam Enslikopedi Alkitab Masa Kini, Jilid 2 (M - Z), ed. J.D. Douglas, terj. Andar Lumantobing, peny. H.A. Omposunggu (Jakarta: Yayasan Komunikasi Bina Kasih, 2011), 142-43.

${ }^{18}$ Dalam bahasa Yunaninya adalah parthenon. Secara harafiah berarti: "since I do not known a man" (bnd.. ayat 56, "Maria kembali ke rumah " dalam bahasa Yunaninya kata "her home" mengindikasikan bahwa dia masih seorang perawan dan belum menikah dengan Yusuf). Hal ini mengungkapkan kondisinya yang kudus.

${ }^{19}$ Maria bertungangan dengan Yusuf dimaksudkan mengikat janji dengannya. Mengikat janji tidak sama dengan pertunangan. Mengikat janji memiliki status hukum yang mana keduanya saling terikat secara hukum, tetapi tidak diperbolehkan tinggal serumah/bersama.. Tahap berikutnya melalui sebuah upacara yang melegatimasi ikatan mereka sebagai suami istri sepenuhnya.

${ }^{20}$ Alkitab BIS menerjemahkan Salam Gabriel (Lukas 1:28), "Salam, engkau yang diberkati Tuhan secara istimewa! Tuhan bersama dengan engkau".

${ }^{21}$ Ungkapan "yang dikarunia" adalah unik di Perjanjian Baru (bnd. kata ini dikenakaan dalam diri Yesus (Luk. 2:40, 53; 4:22). Di Perjanjian Lama istilah tersebut sering yang dijumpai dalam diri Nuh (Kej. 6:8), Musa (Kel. 33:12-17), Gideon (Hak. 6:17) dan Samuel (1Sam. 2:26).

${ }^{22}$ Jean Galot, Mary In The Gospel, (Westminster: The Newman Press, 1965), 16-21.

${ }^{23}$ Ibid.

${ }^{24}$ Dalam bahasa Ibrani nama Yesus berarti "Allah adalah penyelamat."

${ }^{25}$ Darrell L. Bock, Luke, The IVP New Testament Commentary (Downers Grove: InterVersity, 1994), 30.

${ }^{26}$ Bukan hanya satu kali namun sedikitnya empat kali ungkapan "yang diberkati, yang dikaruniai, beroleh kasih karunia” dipakai Lukas untuk tokoh Maria-nya. (1) Pertama tentu saja dalam Lukas 1:28, namun (2) Gabriel-sang Malaikat, sebagai figur sorgawi mengulanginya sekali lagi di ayat 30 untuk meneguhkan Maria, “Jangan takut, hai Maria, sebab engkau beroleh kasih karunia di hadapan Allah. Allah”. (3) Sanak saudaranya, Elisabet juga mengatakan hal yang sama, bahkan dengan suara nyaring, "Diberkatilah engkau di antara semua perempuan dan diberkatilah buah rahimmu” (Luk.1:42). Bahkan lebih luas lagi (4) saat Yesus telah memulai pelayanan-Nya, ungkapan tersebut masih terlontar, kini melalui mulut seorang perempuan yang mendengar pengajaran Yesus dan menyaksikan kiprah-Nya. "Berbahagialah ibu yang telah mengandung Engkau dan susu yang telah menyusui Engkau” (Luk.11:27) Dengan demikian, baik yang di sorga maupun yang di bumi, keluarga maupun orang asing menyebut dan mengenal Maria sebagai "Yang Dikaruniai dan Yang Terberkati" Karenanya, Maria pun memuji Allah, "Sesungguhnya mulai dari sekarang segala keturunan akan menyebut aku berbahagia." (1:48; salam ini disebut sebagi Magnificat).

${ }^{27}$ Joel Green, The Gospel of Luke, The New International Commentary on the New Testament (Grand Rapids: Eerdmans, 1997), 230.

3.

${ }^{28}$ Reaksi Yohanes mengantisipasi dan mencerminkan peran pendahulu yang akan ia miliki dalam Lukas

${ }^{29}$ Robert H.Stein, Luke, The New American Commentary, vol. 24 (Nashville: Braodman \& Holman, 1992), 90 . 